\title{
The Complexity of Coordination Among Indonesian State Intelligence Institutions
}

\author{
Sunarko*, Sumartono, M.R. Khairul Muluk, Bambang Santoso Haryono \\ Faculty of Administrative Science, Universitas Brawijaya \\ Jl. MT. Haryono 163, Malang 65145, Indonesia
}

\begin{abstract}
The reforms in Indonesia have given birth to innovations in institutional arrangement and has become one of the priorities for democracy that is still being fought for. The problem that arises after the reforms have taken place is not all state institutions are arranged and in accordance with the values and principles of democracy, including the arrangement of state intelligence institutions in Indonesia. The existing State Intelligence Institutions (besides Indonesian National Armed Forces (TNI) and Indonesian National Police (POLRI)) have Task Implementation Operational Standards (SOPT) which are based on the duties and capabilities possessed, but are not supported by adequate capacity building, so that these institutions are less able to carry out the mandate stated in Article 2 of Law No. 17 Year 2011. Not all existing National Intelligence Institutions' personnels (besides TNI and POLRI) have professional resource capabilities in the intelligence implementation as mentioned in Article 2 and Article 3 of Law No. 17 Year 2011. Almost most of the people or citizens in Indonesia assess intelligence as someone who is looking for information about crime and only in the scope of POLRI and TNI. The complexity of State Intelligence Institutions' Coordination in Indonesia is not something that needs to be made a scapegoat for the failure of intelligence's tasks. On the contrary, it must be seen as a source to achieve the success in carring out the tasks. Therefore the solution that can be done is by the Development of Capacity Building of the State Intelligence Institutions which is supported by the Network Type Command (NTC) coordination model, namely HTM, MTM and NTM model developments. The NTC model is a large coordination model with a broad network but still under one control or command, so that information processing can become increasingly faster and more accurate which in turn can increase high power in carrying out early detection and warning. This model is also able to make a more significant contribution in developing the operational plans and strategies of state intelligence institutions in order to achieve the role, purpose and function of state intelligence effectively.
\end{abstract}

Keywords: Complexity, Institution, Intelligence, The Republic of Indonesia

DOI: $10.7176 / \mathrm{PPAR} / 9-1-05$

\section{Introduction}

Regarding the intelligence implementation, various forms and sources of information in early detection are a first and fundamental step in administering intelligence operational strategies. Therefore, public administration science is expected to carry out the mandate in providing solutions to various problems, including intelligence institutions in Indonesia. As Frederickson thought that:

"The dynamism of state/public administration in an effort to provide its expediency for the sake of public service has given birth to several models, namely, originating from contemporary state administration, seen from the mindset of classical bureaucratic models that have two important components, namely the structure or framework of an organization and ways used to administer people and jobs within the framework of the organization. Whereas in the neo-bureaucracy model, the emphasis is on the decision making process in the organization. On the other hand, the institutional model emphasizes the discussion of the real pattern of organizational behavior. The human relations model emphasizes the pattern of group dynamics, sensitivity training and organizational development. The public choice model focuses more on promoting employee satisfaction, personal development, individual dignity and public choice, (Frederickson, 2010)".

Compared to other organizations in the security sector, intelligence agency indeed has a factor which is unique from the others, among them is to gather information maximally in order to achieve effective goals. Various problems that occur in the country that are related to intelligence problems are the scope of public administration study, various perspectives can be raised to find solutions to these problems. As Muluk stated that:

"The study and practice of public administration in various countries continues to grow, various changes occur along with the development of the complexity of the problems faced by public administrators. This complexity is responded to by theorists by continuing to develop public administration science. Denhardt \& Denhardt reveals that there are three perspectives in public administration, namely old public administration, new public management, and new public service, (Muluk, 2006)”.

The state intelligence institutions in Indonesia are not only limited to the State Intelligence Agency (BIN), or the Strategic Intelligence Agency (BAIS) which is owned by TNI Headquarters, or also the Security 
Intelligence (Intelkam) of POLRI Headquarters. There are quite a number of state intelligence institutions in Indonesia, as stated in Article 7 of Law No. 17 Year 2011 concerning State Intelligence that the scope of State intelligence includes: a). Domestic and foreign intelligence, b). Defense and/or military intelligence, c). Police intelligence, d). Law enforcement intelligence, and e). Ministerial/non-ministerial government institutions intelligence.

The general duties of the state intelligence institution as mentioned in Article 1 of Law No. 17 Year 2011 concerning State Intelligence are as follows:

1. "Intelligence is knowledge, organization, and activities related to the formulation of policies, national strategies, and decision making based on analysis of information and facts collected through work methods for early detection and warning in the context of prevention, deterrence, and overcoming any threats to national security.

2. State Intelligence is the organizer of intelligence which is an integral part of the national security system which has the authority to carry out the functions and activities of State Intelligence.

3. State Intelligence Personnels are Indonesian citizens who have special intelligence capabilities and are devoted to the State Intelligence service (Law No. 17 Year 2011)".

Based on consideration in point c of Law No. 17 Year 2011, it is stated that; "to conduct early detection and warning to prevent the occurrence of abrupt threats, strong and professional State Intelligence is required, in addition, State Intelligence is required to strengthen cooperation and coordination by respecting the law, democratic values and human rights as mandated in The 1945 Constitution of the Republic of Indonesia". Coordination is needed in order to achieve the objectives or tasks of the state intelligence institutions. Coordination mentioned here refers to a synchronous and orderly effort to provide the right amount and time, and direct the implementation to produce a uniform and harmonious action on the intended target. Coordination and cooperation between effective and efficient intelligence institutions in the Republic of Indonesia is needed in order to realize the integration of intelligence steps and results. Intelligence as a means of completing a government is an important issue. This issue becomes increasingly important when thinking more about the role of intelligence in the future and in global issues.

Based on the background of the problem described, the formulation of the problem in this research is:

1. How is the complexity of coordination among state intelligence institutions in Indonesia?

2. How are the SWOT (Strengths, Weaknesses, Opportunities and Threats) conditions of coordination among state intelligence institutions in Indonesia?

3. How is the reform of the coordination of state intelligence institutions in achieving the success of the intelligence task implementation?

4. How is the effective and efficient model of coordination among state intelligence institutions in Indonesia?

Based on the formulation of the problem above, the objectives in this research are to:

1. Describe and analyze the complexity of coordination among state intelligence institutions in Indonesia

2. Describe and analyze the SWOT (Strengths, Weaknesses, Opportunities and Threats) conditions of coordination among state intelligence institutions in Indonesia

3. Describe and analyze the reform of the coordination of state intelligence institutions in achieving the success of the intelligence task implementation

4. Find and develop effective and efficient model of coordination among state intelligence institutions in Indonesia

The results of this research are expected to provide the following contributions:

a. Contribute to the development of public administration science seen from the point of coordination in an institution (Scott, 2008). Coordination becomes the most important part so that the implementation of tasks can run well, it is necessary to carry out administrative functions, especially in the administrating organization so that the organization is able to carry out the activities that are its responsibility.

b. Can broaden the theoretical horizons of public administration in connection with institutional coordination (Scott, 2008) in the transformation and reform between state intelligence institutions. Because coordination problems still need to be solved, KIS (Coordination, Integration, and Synchronization) is provided as a guideline so that the implementation of the main tasks of the organization is successful. Therefore, integration needs to be carried out in unity of action. It is expected that the synchronization is harmonious, balanced, and consistent with each other.

c. As consideration and input for relevant parties, especially state intelligence institutions in Indonesia, namely in policies and efforts to take steps related to coordination policies in the transformation and reform of the State Intelligence Agency in the perspective of institutional theory.

d. As a recommendation material in activities and coordination policies in the transformation and reform of state intelligence institutions in Indonesia, so that they are more precise on the targets, methods and in accordance with their objectives.

e. As a reference for other researchers who have an interest in researching with the same scope and focus of 
research.

\section{Literature Review}

The New State Administration is a call that demands public administration's independence against political science domination and scientific attachment to political science. But unfortunately, the call failed in the intellectual development of the public administration science, but public administration was regarded as "the New Politics of Bureaucracy". The scientific journey of state administration finally returned to state administration again in the 1970s. Here comes the studies of state administrations which focus on "organizational theory and management science" and locus on "public interest and public affairs". According to Zauhar (2001: 57), there are 5 (five) reasons why public administration theory is important, the five reasons include:

a. Public administration theory states something meaningful, which can be applied to real life situations;

b. Administrative theory can present a perspective;

c. Administrative theory stimulates the birth of new ways in different things,

d. The existing administrative theory can be the basis for developing other administrative theories, and

e. Administrative theory helps its users to explain and predict the phenomena faced by them.

According to Sange (1987, in Anggoro, 2008: 42), he stated that coordination is "the process of integrating goals and activities in separate units (departments or functional fields) of an organization to achieve organizational goals efficiently". Coordination is one of the very important stages of work to be carried out in administering a system of administration. According to Khamdani (2014: 26), Coordination is: "Coordination as the achievement of orderly group efforts, and unity of action in the pursuit of common purpose". Verhoest and Bouckaert (2010: 40-49) stated that the coordination mechanism has three models as follows.

1. Coordination with Hierarchy Type Mechanism (HTM)
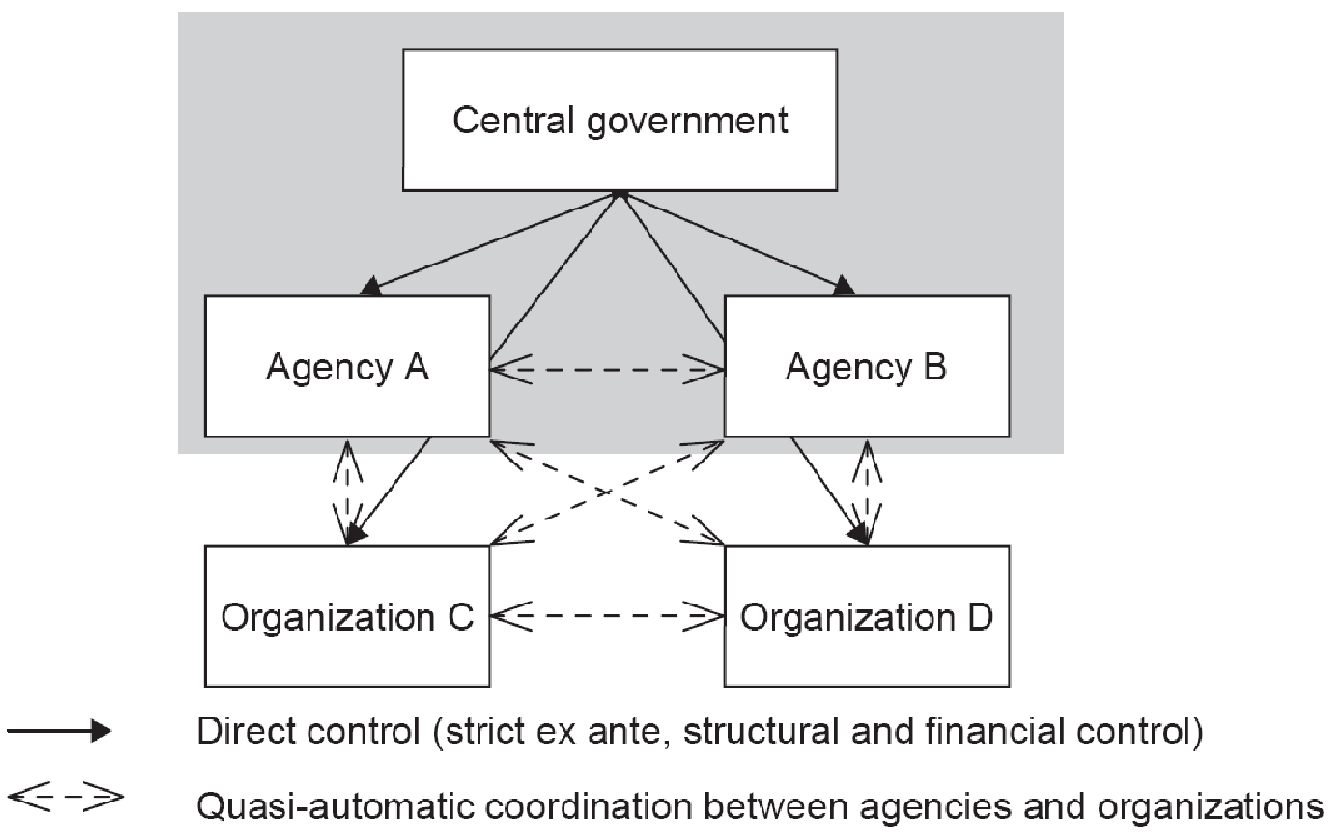

\section{Public sector}

Figure 1. Coordination with HTM Model

Source : Verhoest and Bouckaert (2010:40)

HTM refers to a set of coordination mechanisms that are based on authority and dominance. It involves setting goals and rules, assigning tasks and responsibilities and establishing lines of direct control and accountability. Both management instruments (such as procedures, top-down planning systems or financial management systems) and structural instruments (such as organizational mergers, coordination functions, direct lines of control and accountability) can be used. As stated by Verhoest and Bouckaert (2010: 39) that: "The feature common to all these expressions of the hierarchical coordination mechanism is that authority and power are used to make coordination more or less automatic among organizations and programmes, or at least are used to impose coordination on organizations and individuals. Public organizations' activities are coordinated by the direct control by the government of individual public organizations". 


\section{Coordination with Market Type Mechanism (MTM)}

MTM is based on competition and exchanges between actors, aiming to create incentives for performance. Although the market establishes 'spontaneous' coordination among market participants, the government can 'intentionally' encourage coordination with competition among organizations.

In this case, Verhoest and Bouckaert (2010: 39) stated that : (MTM) "shows the optimal operation of coordination through market-type mechanisms. The coordination of public organizations is mainly 'horizontal' self-coordination induced by the forces of price, competition, supply and demand. Relations between public organizations are mainly based on contractual exchange. The government mainly acts as a market creator and regulator. To the extent that government controls public providers, this control is mainly indirect and ex-post in nature".
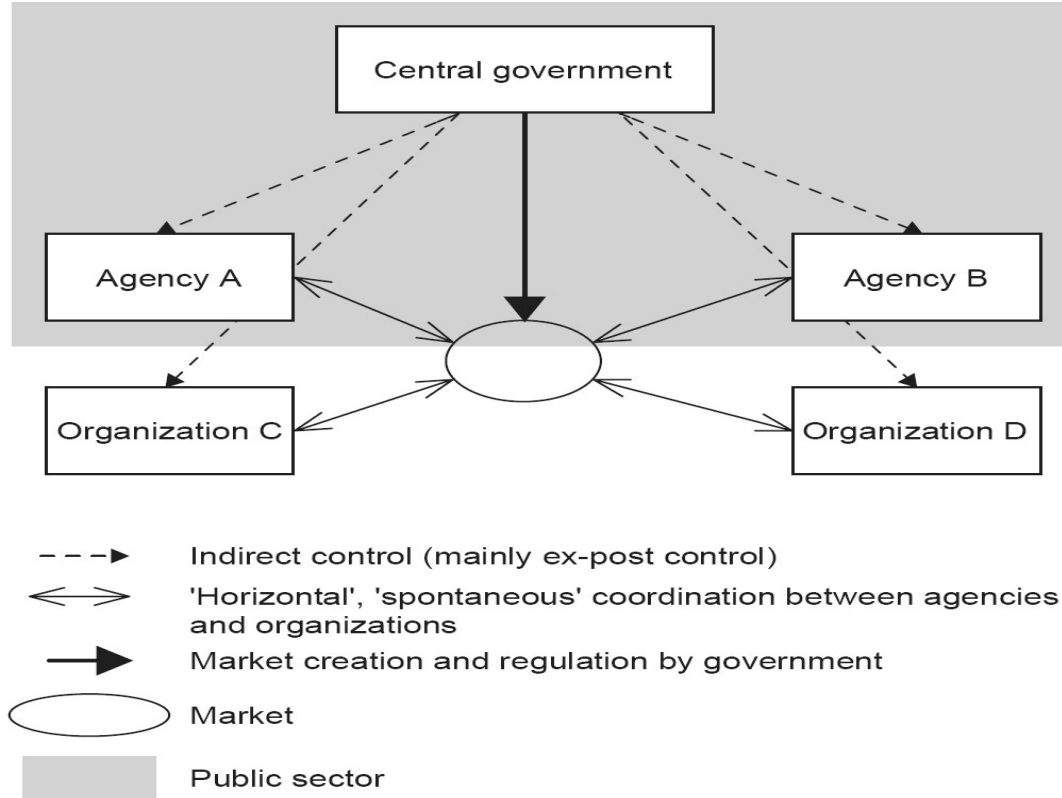

Figure 2. Coordination with MTM

Source : Verhoest and Bouckaert (2010:44)

3. Coordination with Network Type Mechanism (NTM)

NTM is based on mutual dependence and trust. The use of NTM is for the formation of general knowledge, general values and general strategies between coordination partners.

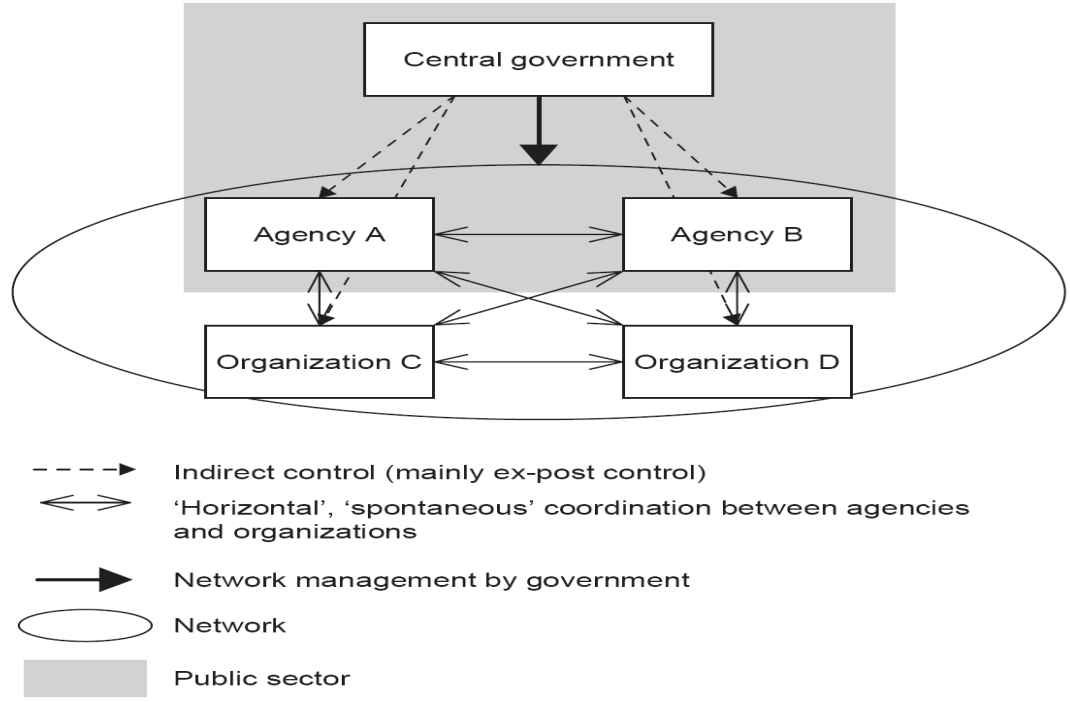

Figure 3. Coordination with NTM Model

Source : Verhoest and Bouckaert (2010:49)

While most coordination networks grow 'spontaneously' between the organizations involved, the 
government can create, take over and maintain a network structure between organizations, for example, with the creation of general information systems, connected structures, collective decision making, or even general organizational partnerships. Inter-organizational learning instruments such as cultural management can foster shared knowledge and values. The main element of coordination is the network, where coordination occurs horizontally between public sector organizations, with the main actor is the government as the network manager.

With this coordination, it is expected that harmony and consistency of all activities can achieve the expected goals, so that the burden of each part becomes harmonious, balanced and consistent. Based on previous research studies that have been presented and the thoughts of the experts presented in this chapter, the research on: "The Complexity of Coordination Among Indonesian State Intelligence Institutions" resulted in the following conceptual framework.

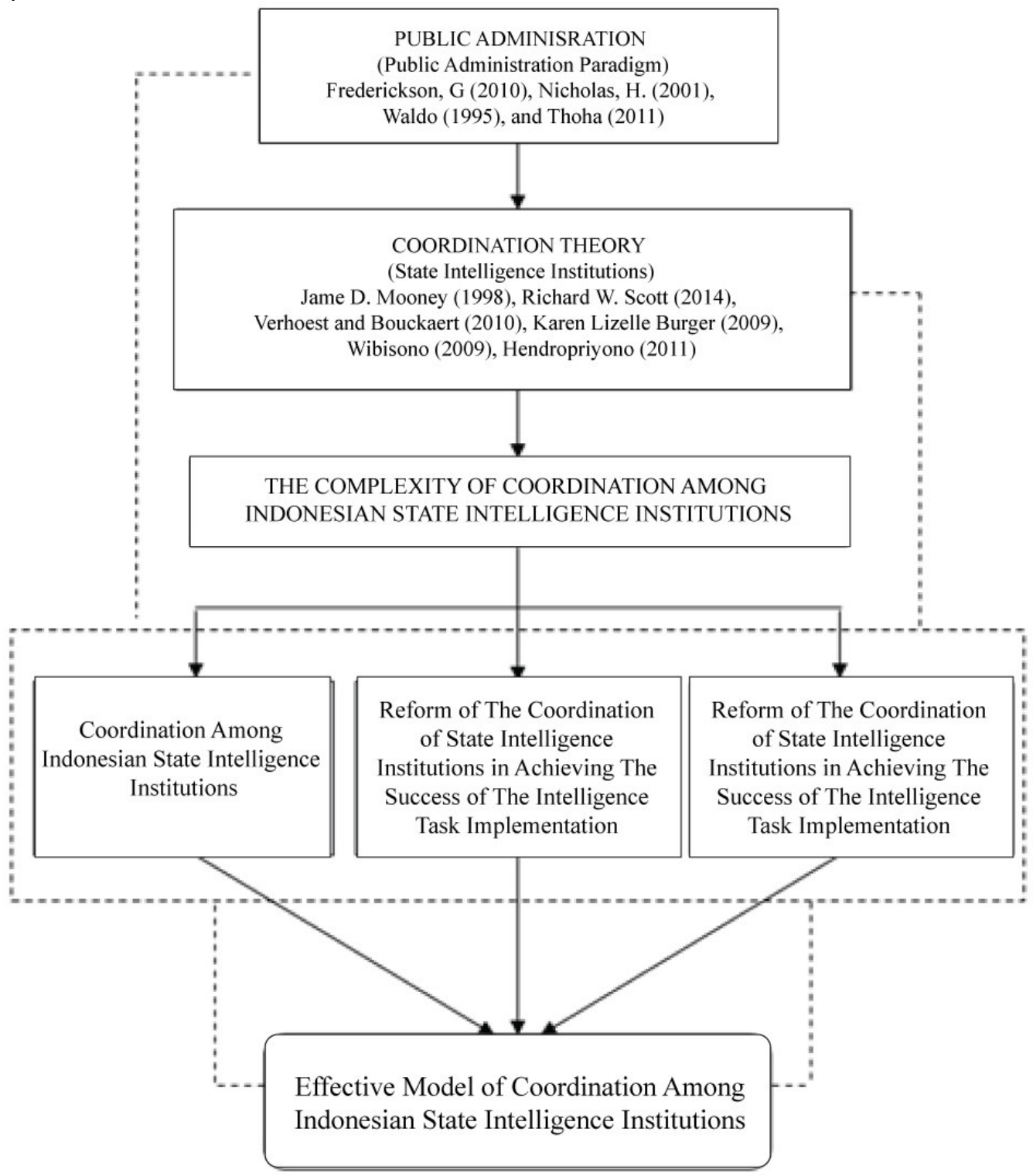

Figure 4. Conceptual Framework

\section{Method}

This research uses a type of qualitative research. According to Sinuff et al. (2007: 87) the purpose of qualitative research is to develop concepts that help to understand social phenomena in natural settings, emphasizing understanding, experience and seeing participants.

Primary data collection in this research uses interviews while secondary data collection uses documentation, then the data analysis of this research uses SWOT analysis and the qualitative research model of research is 
sharpened with the interactive data analysis model developed by Miles, Huberman and Saldana (2014), which is known as interactive models as presented in the following figure.

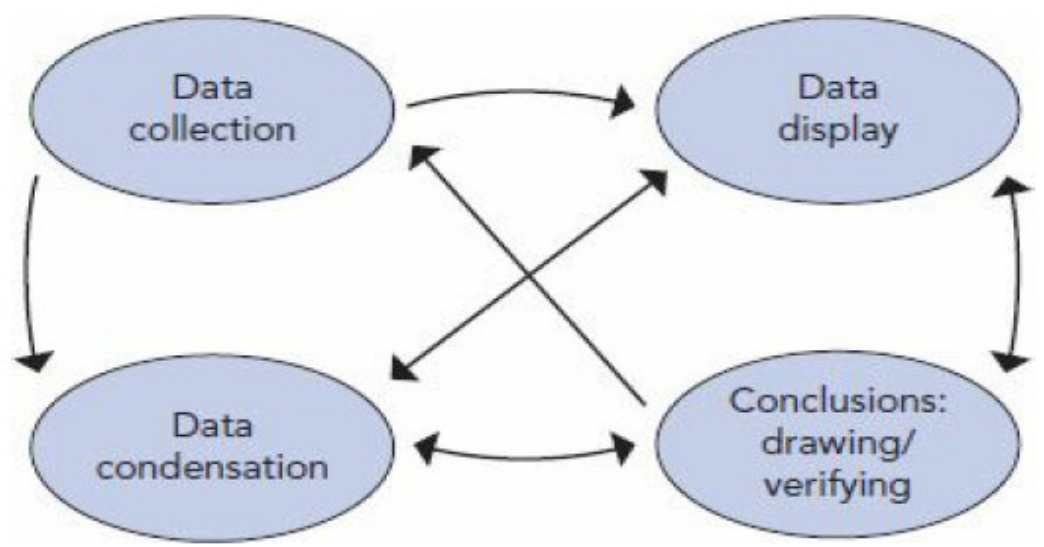

Figure 5. Components of Interactive Data Analysis

Source : Miles, Huberman dan Saldana (2014:33)

Data analysis supported by SWOT matrix analysis can illustrate clearly how the opportunities and threats faced and adapted to the existing strengths and weaknesses.

\begin{tabular}{|l|l|l|}
\hline EFAS & $\begin{array}{l}\text { STRENGTH (S) } \\
\text { Determine 5-10 internal } \\
\text { strength factors }\end{array}$ & $\begin{array}{l}\text { WEAKNESS (W) } \\
\text { Determine 5-10 internal } \\
\text { weakness factors }\end{array}$ \\
\hline $\begin{array}{l}\text { OPPORTUNITY (O) } \\
\text { Determine 5 - 10 external } \\
\text { opportunity factors }\end{array}$ & $\begin{array}{l}\text { STRATEGY S - O } \\
\text { Create a strategy that uses } \\
\text { strength to take advantage } \\
\text { of opportunities }\end{array}$ & $\begin{array}{l}\text { STRATEGY W - O } \\
\text { Create a strategy that } \\
\text { minimizes weaknesses to } \\
\text { take advantage of } \\
\text { opportunities }\end{array}$ \\
\hline $\begin{array}{l}\text { THREATS (T) } \\
\text { Determine 5-10 external threat } \\
\text { factors }\end{array}$ & $\begin{array}{l}\text { STRATEGY S - T } \\
\text { Create a strategy that uses } \\
\text { strength to overcome } \\
\text { threats }\end{array}$ & $\begin{array}{l}\text { STRATEGY W - T } \\
\text { Create a strategy that } \\
\text { minimizes weaknesses and } \\
\text { avoid threats }\end{array}$ \\
\hline
\end{tabular}

Figure 6. SWOT Analysis Matrix

Source : Yukl (2010)

\section{Findings and Discussion}

The legal basis for coordination among Intelligence institutions in Indonesia is in accordance with Article 28 paragraph (2) of Law No. 17 Year 2011 concerning State Intelligence, which stated that; "The State Intelligence Agency (BIN) administers the coordinating function of the State Intelligence". Furthermore, it is clarified in Chapter VII of Law No. 17 Year 2011. Then in further explanation, it is stated in Presidential Regulation No. 90 Year 2012 concerning the State Intelligence Agency. Based on the existing Laws and Regulations, the State Intelligence Agency is structurally the authorized body in the implementation of coordination among state intelligence institutions in Indonesia.

There is not yet a place that unites in the implementation of coordination among state intelligence institutions in Indonesia. So far, the coordination that often arises in state intelligence institutions is internal coordination, such as coordination between TNI intelligence leaders and their members, coordination between POLRI intelligence leaders and their members, or coordination between TNI and POLRI intelligence leaders and their members.

There are quite numerous intelligence institutions in Indonesia, but there is rarely coordination among these intelligence institutions. This is due to the strong ties and interdependence of the coordination among state intelligence institutions in Indonesia which causes more internal intelligence coordination among intelligence institutions, if BIN is considered as a body that has the coordination authority of state intelligence institutions as contained in Article 28 of Law No. 11 Year 2011 concerning BIN. However, the Deputy of Intelligence Coordination or Intelligence Coordination Expert Staff have not yet been listed in BIN's structure. Nevertheless, there is no part that has full duty and responsibility to strengthen and bind the implementation of coordination among state intelligence institutions until today. Therefore, it can be said that intelligence presents in various institutions and departments runs on its own.

There is an understanding from the legal basis that the intended coordination is only limited to the 
coordination of state intelligence in the TNI and POLRI circles. Whereas, Indonesia has quite a lot of intelligence, which maybe even more than some other countries in the world, including TNI, POLRI, Attorney, Judiciary, Customs, Department of Home Affairs, Department of Foreign Affairs, including a low level intellogence in communities such as Civil Defense (Hansip) and People Security Force (Kamra).

Based on the description that has been mentioned above, the state intelligence institutions must be supported by various resources and aspects in carrying out their duties, one of the elements that are considered important in ensuring the operational and smooth functioning of state intelligence is coordination. As mentioned earlier that coordination is important for the organization. According to Terry (1968), "coordination is a business that is synchronous and orderly to provide the right amount and time and direct implementation to produce a uniform and harmonious actions at predetermined goals". In view of this opinion, coordination among state intelligence institutions is a business that is synchronous and regulated based on a legal force (Laws and Regulations) to provide the right amount and time that is useful in directing actions to produce uniform and harmonious activities at the targets set in achieving the aim of state intelligence institutions to protect the interests of the security and integrity of the country.

Coordination among state intelligence institutions is one of the factors that contributes to achieving the objectives and tasks of intelligence institutions. Through effective coordination, the state intelligence institutions are able to collect data and process information well, quickly and precisely. Some of the foreign intelligence institutions mentioned also involve civil society in operations and coordination, which is proven to be able to provide significant results in supporting the tasks and objectives of state intelligence institutions. In accordance with the results of the research presented, a following model of coordination among Indonesian State Intelligence Institutions can be made.

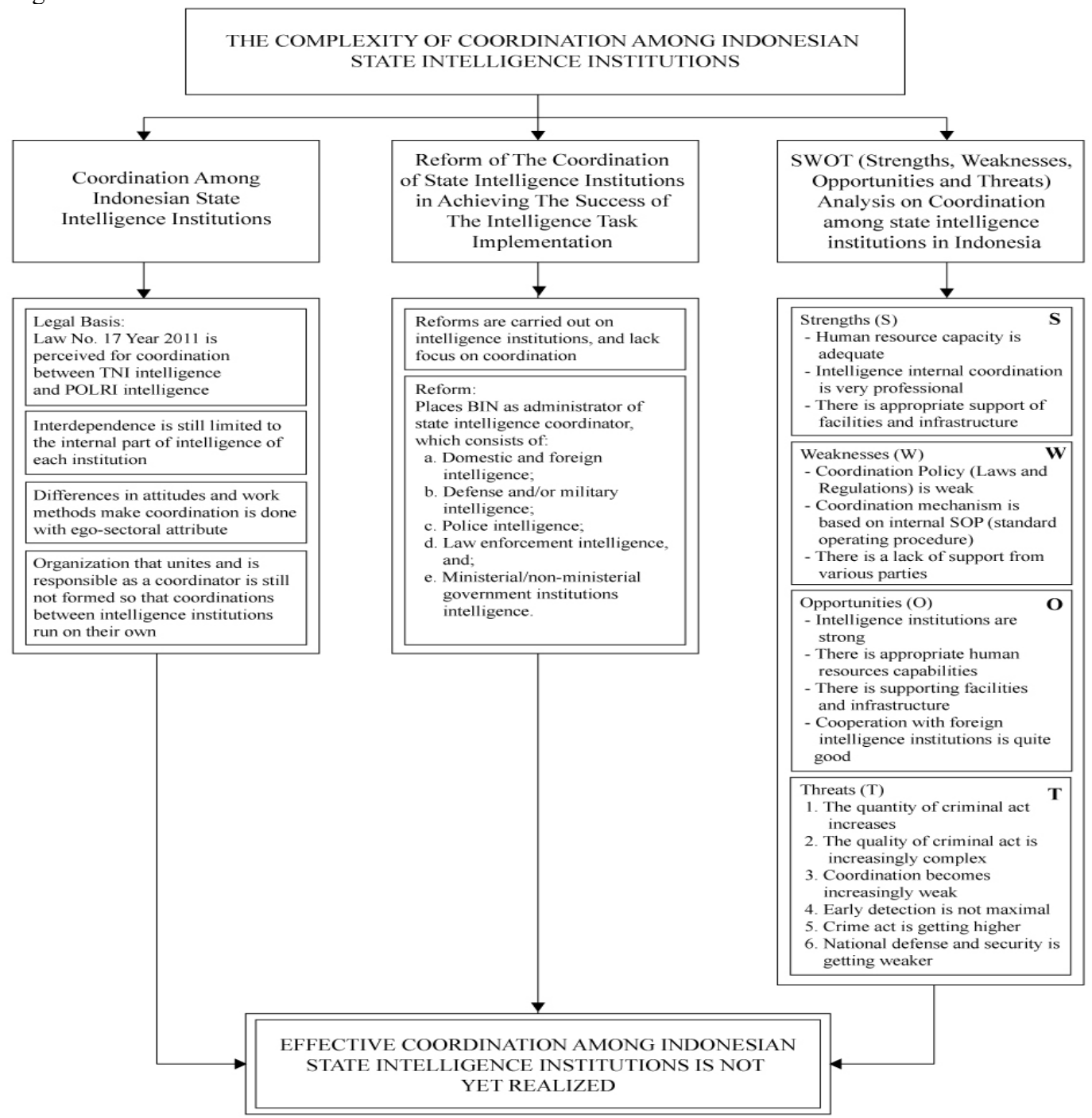

Figure 7.Existing Model: The Complexity of Coordination Among Indonesian State Intelligence Institutions 


\section{SWOT Analysis (Strengths - Weaknesses - Opportunities - Threats) of Coordination among state intelligence institutions. \\ 1. Strengths}

Based on the focus of this research, our country's intelligence is getting better and it also has sufficient human resource capabilities as well as facilities and infrastructure. Even our state intelligence can be developed more professionally and steadily in the future due to the existence of State Intelligence Academy (STIN). The focus of this research found that:

a) The existing state intelligence, especially the TNI, is very capable of supporting the realization of the country's national goals to protect the entire Indonesian nation and the entire land of Indonesia.

b) The existing state intelligence, especially the TNI, is capable of early detection and warning to prevent the occurrence of abrupt threats which require strong and professional State Intelligence, in addition, State Intelligence is required to strengthen cooperation and coordination by respecting the law, democratic values and human rights as mandated in The 1945 Constitution of the Republic of Indonesia;

c) The existing state intelligence, especially the TNI, is able to anticipate the development of the situation, and strategic environmental conditions, the need to conduct early detection and warning of various forms and characteristics of threats, both from domestic and abroad that are complex and have a very broad spectrum;

d) The fundamental problem that still shows is that there is a lack of coordination among the existing state intelligence institutions in Indonesia so that the existing state intelligence institutions seem to run individually based on the Standard Operating Procedure (SOP) set by each intelligence institution.

\section{Weaknesses}

Based on the focus of this research with regard to weaknesses in coordination, there are some fundamental problems with regard to coordination among state intelligence institutions, namely;

1). The legal basis for coordination is still weak

The intelligence Law No. 17 Year 2011 is still vague so that there has not been a specific explanation for coordination. In addition, the Presidential Decree No. 90 Year 2012 concerning the state intelligence agency has not clearly elaborated the implementation of coordination of our country's intelligence institutions.

2). BIN's organizational structure is still not supportive

When viewed from the Organizational Structure of the State Intelligence Agency, configuration of state intelligence coordination has not yet been made in the structure.

3). Ambiguous coordination standards

Every intelligence institution in our country has its own standards so that BIN as an intelligence coordinator has not been able to reach out to the coordination of all existing intelligence institutions.

4). Separate coordination

The separation of the TNI and POLRI for internal security has been taken by POLRI makes the coordination has also become fragmented, especially with other intelligence institutions. Whereas the TNI, POLRI and other intelligence institutions must cooperate for domestic and foreign security.

\section{Opportunities}

The need for strategic information is delegated in the form of institutional authority manifested in an intelligence infrastructure consisting of the determination of intelligence functions. In connection with the focus of opportunities, there are two main aspects obtained from this research, namely;

a). Internal Opportunities

Internal coordination among state intelligence institutions is the coordination that is carried out between state intelligence institutions such as between TNI intelligence and Ministry of Defense, or Intelkam intelligence with POLRI and other intelligence with its services.

The coordination of intelligence institutions in Indonesia is actually an opportunity for intelligence coordination within the country that can be said as a form of internal opportunity, this opportunity is that our country's intelligence institutions have members (quantities) that are adequate with good quality support. There is an intelligence institution in every area of the Republic of Indonesia which is called as regional intelligence, in which this regional intelligence institution plays a role in detecting threats, maintaining the security and integrity of the Republic of Indonesia.

Another internal opportunity is the ability of the resources possessed by our country's intelligence institutions, namely infrastructure, technology and information that are sophisticated enough to support the implementation of coordination.

b). External Opportunities

External coordination among state intelligence institutions is the opportunity for coordination among state intelligence institutions and foreign countries, this opportunity, among others, with embassies outside the country, the cooperation of our state intelligence institutions with some intelligence in countries in the world. With the existence of this collaboration, it is very beneficial to achieve the main goal of our country's intelligence institutions, namely to detect threats and to maintain the security and integrity of the Republic of 
Indonesia.

\section{Threats}

Threats are things that can bring threats or losses originating from outside and influence the coordination activities between state intelligence institutions in Indonesia. The task of state intelligence institutions cannot be separated from national security and defense. The results of research related to threats in coordination among state intelligence institutions in Indonesia in this research have several findings, including;

a) There is a lack of attention and concern from political figures, bureaucratic figures, economic figures, public figures, academic figures and diplomatic figures in supporting the interests of coordinating our country's intelligence agencies.

b) The weakness of the laws and regulations on state intelligence if seen from the existing laws and regulations: coordination is still perceived only for TNI and POLRI.

c) The State Intelligence Agency (BIN) acts as the coordinator of state intelligence institutions in Indonesia. However, there is no configuration for the coordination section in the BIN's organizational structure. Therefore, it is unclear where the intelligence must coordinate.

d) There is a weak relations between intelligence and civilians, for example, civil society tends to close themselves if there is intelligence comes to their place, this is certainly affects intelligence's capabilities in early detection.

e) The budget for operating state intelligence is still inadequate so that it is difficult to routinely coordinate between state intelligence institutions

f) There is still a strong opinion about "black intelligence - intelligence is categorized as a bad activity" in the community that makes our state intelligence institutions are seen as if they were parasites for the community.

g) Legal umbrella for intelligence members in carrying out tasks is still not strong enough so that they are always haunted by "violations of human rights" in carrying out their duties.

\begin{tabular}{|c|c|c|}
\hline 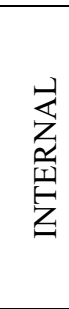 & $\begin{array}{l}\text { STRENGTHS } \\
\text { 1) Intelligence's loyalty on the Republic of } \\
\text { Indonesia } \\
\text { 2) HR capability is sufficient } \\
\text { 3) The existence of STIN } \\
\text { 4) There is regional intelligence } \\
\text { 5) There is a clear SOP } \\
\text { 6) Facilities and infrastructure are sufficient }\end{array}$ & $\begin{array}{l}\text { WEAKNESSES } \\
\text { 1. The legal umbrella is still weak } \\
\text { 2. Organizational arrangement is less } \\
\text { supportive } \\
\text { 3. The budget is still small } \\
\text { 4. Collaboration is less effective } \\
\text { 5. Lack of support from various parties } \\
\text { 6. Fear of Human Rights Violations }\end{array}$ \\
\hline 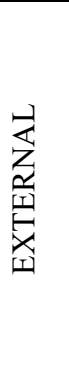 & $\begin{array}{ll}\text { Opportunities } \\
\text { 1. Development of intelligence's HR capacity } \\
\text { 2. Development of a more robust SOP } \\
\text { 3. Improvement of facilities and infrastructure } \\
\text { 4. Technology and Information Innovations } \\
\text { 5. Cooperation with better foreign State } \\
\text { Intelligence Institutions }\end{array}$ & $\begin{array}{l}\text { Threats } \\
\text { 1. The quantity of criminal act increases } \\
\text { 2. The quality of criminal act is increasingly } \\
\text { complex } \\
\text { 3. Coordination becomes increasingly weak } \\
\text { 4. Early detection has not been achieved } \\
\text { financially } \\
\text { 5. The crime act is getting higher } \\
\text { 6. National Defense and Security is getting } \\
\text { weaker }\end{array}$ \\
\hline
\end{tabular}

Figure 8. SWOT Analysis of Coordination Among State Intelligence Institutions

Source: Processed Research Results (2017)

The problem of coordination among state intelligence institutions is very important for state intelligence institutions in Indonesia. If the coordination between intelligence institutions is very strong, the cases I mentioned above may be detected early and the consequences may not be as severe as now. Even coordination reform is increasingly deemed necessary because of the increasingly sophisticated science and technology, which can pose a threat to the Country. Not much different from the information that the researchers got before, that according to the opinion of the resource person that has been presented by the researchers previusly, the problem of coordination of this state intelligence institutions indeed needss to be sharpened. What has been done so far is state intelligence reform, so that coordination reforms of state intelligence institutions need to be carried out. If reviewed from a legal basis that regulates the functions and roles of intelligence services that are currently in force, the law and regulations provide policies to BIN as the state intelligence coordinator in general. However, to achieve the task objectives of state intelligence, the existing laws and regulations have not been as specific as managing coordination among state intelligence institutions, so that misperceptions still occur in the implementation of tasks.

The sustainable principles of coordination among state intelligence institutions in Indonesia are a "package" of good coordination, which must be contained in environmental policies that are embodied in the instruments of 
environmental legislation. Harmonization of the principle of coordination among state intelligence institutions in Indonesia also has implications for:

1. The stronger drive towards coordination among state intelligence institutions in Indonesia (including the demands of the international community);

2. The society will be more open and democratic (democratic society and government) in assessing coordination among state intelligence institutions in Indonesia

3. The strengths of civil society as a support group need to be built effectively;

4. The Rule of Law is increasingly built in coordination among state intelligence institutions in Indonesia

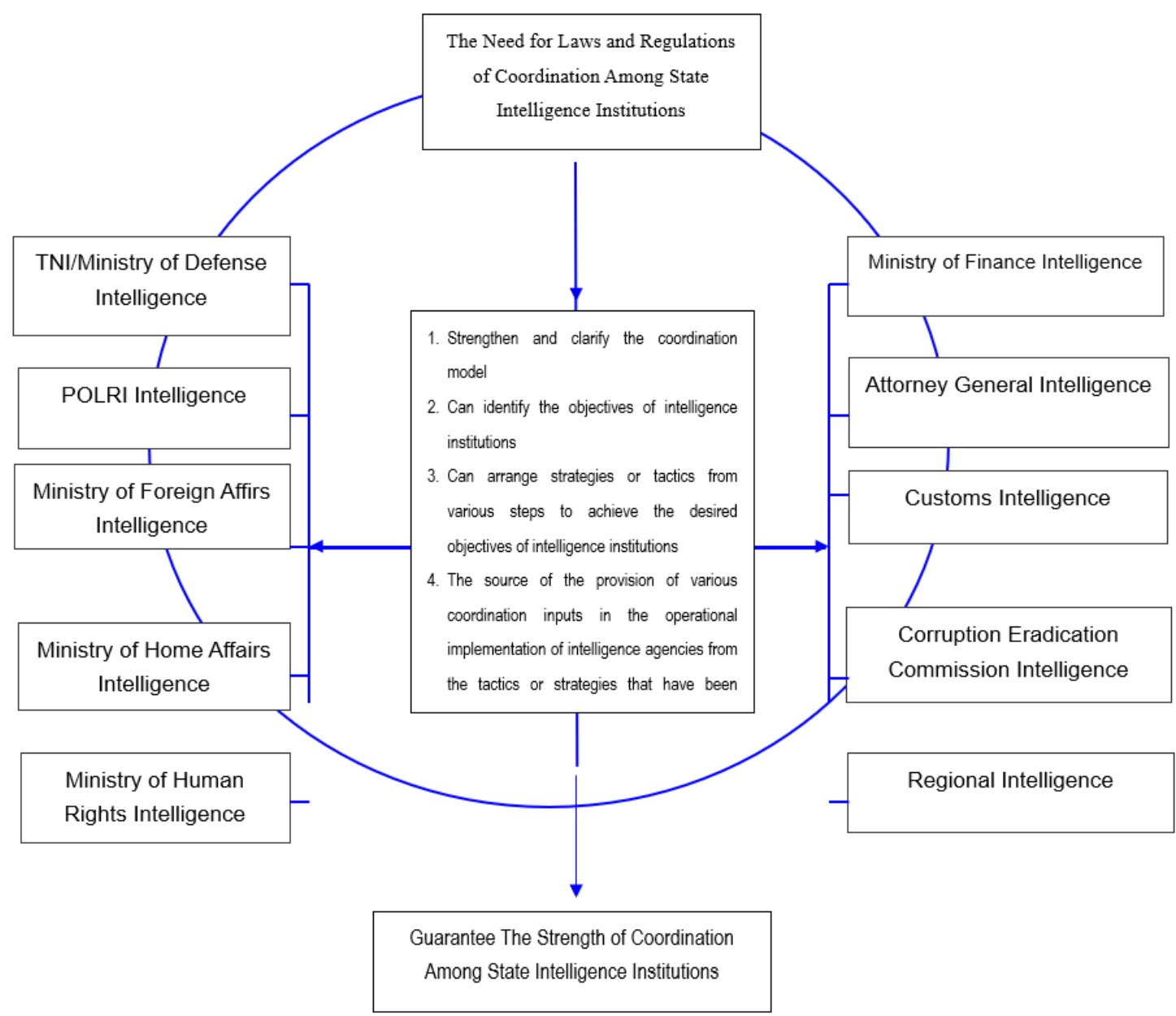

Figure 9. The Need for Laws and Regulations as Guarantor of Coordination Among the State Intelligence Institutions

Source : Processed Research Results (2017)

Coordination among state intelligence institutions can be carried out using a reciprocal adjustment coordination mechanism because relationships between individuals and units have reciprocal interdependence, whereas between sequential interdependent relationships the coordination mechanism is based on planning. Based on the thoughts that have been conveyed, the following model of interdependence in the coordination among state intelligence institutions in Indonesia can be made. 


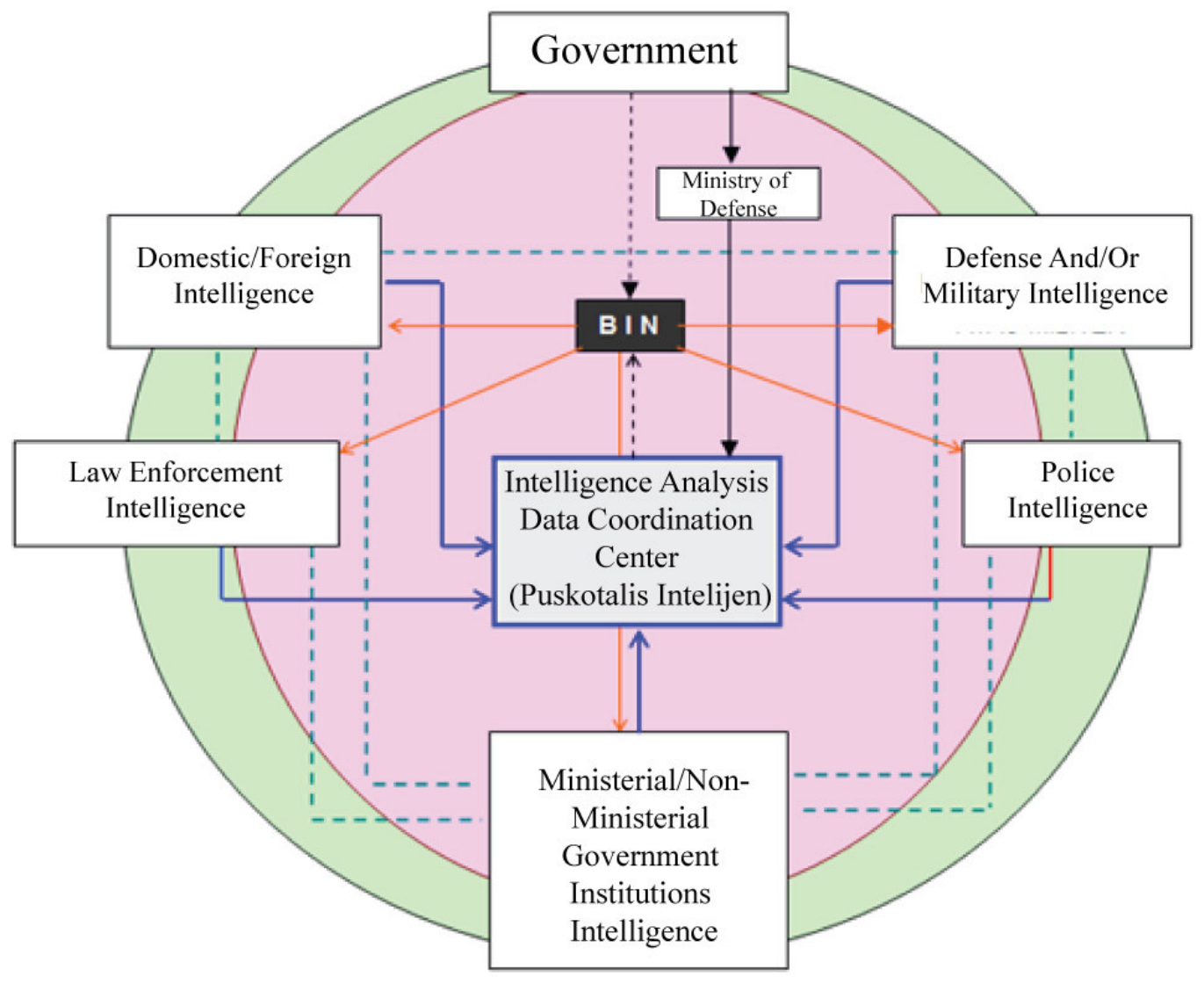

Figure 10. Proposed Model of Coordination Among Intelligence Institutions Using Network Type Command (NTC) Model

Source : Verhoest and Bouckaert (2010), processed by the researchers

Description :

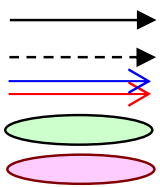

Direct control

Indirect control

Coordination

Internasional

REPUBLIC OF INDONESIA (Public, Politics, Private

Parties, and others)

The model presented is a Network Type Command model. This model is also in accordance with the Chart of the USA intelligence organization where there is a DNI which has the main authority in coordinating intelligence tasks and coordinating intelligence activities between departments and government. The proposed coordination can provide adjustments from each part, and efforts to move and operate parts at a suitable time (part in time), so that each part can make the most contribution to the overall results. The thought of coordination using Network Type Command (NTC) presented is also in line with the thoughts of Verhoest and Bouckaert (2010: 25) which mentioned that: "The logic of approaching coordination as a political rather than administrative activity is that the legitimacy and political power necessary to push and prod organizations out of their established patterns of delivering policies through 'silos' is vested largely in political leaders rather than in administrators. Producing effective, coordinated policy action requires making government go against many ingrained patterns of making decisions and managing programmes, and most administrative officials will have few incentives to engage in that type of battle. Therefore, political leaders may need to utilize their legitimate power in government to change such ingrained patterns".

The most important consideration is that any coordination problems faced by state intelligence institutions need to get full attention, so that the threat to national defense and security can be increased. Based on the results of the ideas that have been presented based on the latest research studies, the study of the theory of Wilson (1989), Mintzber (1996), Verhoest (2010), the ideas of Karen (2008), Jeffray (2016), and William (2017: 104), the recommended model of coordination among the State Intelligence Institutions that are effective in 
intelligence implementation in Indonesia can be seen below.

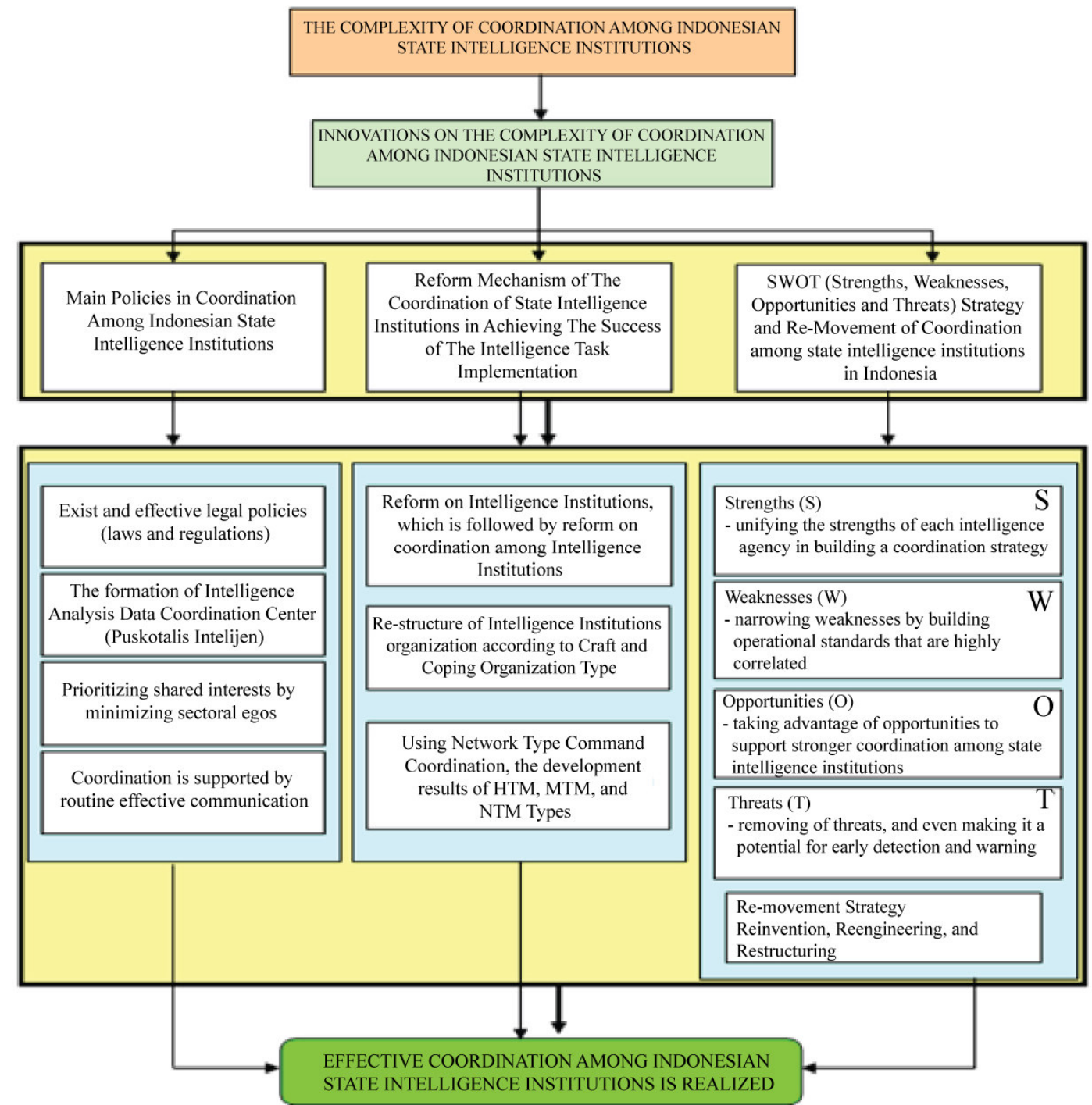

Figure 11. Recommended Model: Effective Coordination Among State Intelligence Institutions

\section{Conclusion}

In the closing section, four main conclusions are formulated which are arranged from the focus of the study, the presentation of the results of the research and the discussion so that it can provide answers to the problems and objectives of this research.

1. Complexity of coordination among state intelligence institutions in Indonesia, which consists of:

a. The legal basis for the policy of regulating the implementation of coordination among state intelligence institutions in Indonesia is Law No. 17 Year 2011 concerning State Intelligence. Explained in Article 28 that; "The State Intelligence Agency (BIN) administers the coordinating function of the State Intelligence". Article 7 states: "The scope of State intelligence includes: a). Domestic and foreign intelligence, b). Defense and/or military intelligence, c). Police intelligence, d). Law enforcement intelligence, and e). Ministerial/non-ministerial government institutions intelligence."

b. This research found a misperception of the legal basis of the implementation of coordination, which is perceived as an implementation of coordination of TNI and POLRI. Interdependence between the implementation of coordination among state intelligence institutions in Indonesia seemed weak, because coordination is more internal to intelligence institutions so that coordination implementation is carried out individually. So far, the coordination that often arises in state intelligence institutions is internal coordination, such as coordination between TNI intelligence leaders and their members, coordination between POLRI intelligence leaders and their members, or coordination between TNI and 
POLRI intelligence leaders and their members.

c. Regarding the differences in attitudes and ways of working in the implementation of coordination among state intelligence institutions in Indonesia, the results obtained prove that attitudes and ways of working are quite significant, given the different duties and authorities of state intelligence institutions. This condition has a quite complex impact on efforts to unite coordination among state intelligence institutions. However, it is also explained that differences in attitudes and ways of working in the implementation of coordination need not be questioned in depth. Important things that need to be considered are looking for solutions to coordinate accordingly to achieve intelligence roles, objectives and functions.

d. Regarding an organization that unites coordination among state intelligence institutions in Indonesia, the constitution of the organization formed is BIN, this is in accordance with Article 28 of Law No. 17 Year 2011 which states; "The State Intelligence Agency (BIN) administers the coordinating function of the State Intelligence". However, if viewed in the organizational structure of BIN, there is still no part and official that has full authority to be fully responsible for coordinating the state intelligence institutions.

2. SWOT (Strengths, Weaknesses, Opportunities and Threats) conditions of coordination among state intelligence institutions in Indonesia.

a. Strengths: the existing state intelligence institutions have a high loyalty to the country, have adequate resource capacity, are professional and can be developed. Operations have been supported by sophisticated technology and facilities, including the State Intelligence Academy (STIN) and the existence of good cooperation with foreign state intelligence institutions.

b. Weaknesses: the legal basis (Laws and Regulations) still do not provide a discourse that fits the needs of coordination among state intelligence institutions. The BIN organization as the organizer of the coordination function is less supportive, the different operational standards set by each intelligence institutions causes separate coordination. Therefore, BIN as the coordinator of the state intelligence institutions has not been able to carry out its function as the coordinator of all intelligence intitutions.

c. Opportunities are divided into two, namely;

1) Domestic opportunities

For domestic opportunities, it can be said as a form of internal opportunity. This opportunity is a state intelligence institutions that have members (quantity) that are adequate with the support of good quality. There is an intelligence institution in every area of the Republic of Indonesia which is called as regional intelligence, in which this regional intelligence institutions play a role in detecting threats as well as maintaining the security and integrity of the Republic of Indonesia. Other internal opportunities are the ability of resources possessed by state intelligence institutions, namely adequate facilities and infrastructure, sophisticated technological support so that they strongly support the implementation of coordination.

2) Foreign opportunities

For foreign opportunities, it can be said as a form of external opportunity. This opportunity is in the form of cooperation of state intelligence institutions with some foreign intelligence institutions in the world. With the existence of this collaboration, it is very beneficial to achieve the main objectives of the state intelligence institutions to detect threats early as well as to maintain the security and integrity of the Republic of Indonesia.

a. Threats in coordination are divided into two, namely;

1) Internal aspects

Internally, this threat is a threat to coordination originating from within the state intelligence institutions themselves, namely; the lack of clarity of the legal umbrella that forms the basis of coordination activities, the weakness of the organizational structure that handles coordination and the lack of attention of high-ranking state officials on the importance of coordination for state intelligence institutions. On the other hand, coordination activities between state intelligence institutions run on their own, so that the relationship between members of the state intelligence in intelligence institutions becomes less harmonious.

2) External aspects

Externally, this threat is in the form of small budget given to state intelligence institutions so that coordination activities between state intelligence institutions are rarely carried out. Negative opinions have been lied to by state intelligence institutions so that they are not supported by civil society.

3. Reform of the Coordination of State Intelligence Institutions in Achieving the Success of the Intelligence Task Implementation.

a) Intelligence institutional reform has been carried out, namely by placing the position of each 
intelligence institution in accordance with the roles, objectives and functions and scope of the intelligence institutions so that intelligence institutions are formed separately according to their capacity.

b) With conditions like this, coordination among state intelligence institutions runs on its own, where coordination is more focused on internal intelligence institutions.

Reforms in the implementation of coordination among state intelligence institutions have not been adequately covered. Threfore, uniting the implementation of coordination among state intelligence institutions is still an obstacle both technically and operationally in the implementation of coordination among intelligence agencies.

4. The focus of Model of Coordination between state intelligence institutions that are effective in intelligence implementation in Indonesia, concludes:

a. The existing legal basis, namely Law No. 17 Year 2011, is incidental so that it has not given full authority to state intelligence institutions in carrying out their duties and functions.

b. Effective coordination between intelligence institutions in Indonesia has still not been able to be achieved effectively, because the basic policy of implementing coordination (legal basis) is perceived to be limited to coordination for TNI and POLRI.

c. The coordination model used is the Hierarchy Type Mechanism (HTM), which is coordination that refers to a coordination mechanism based on authority and dominance, so that it is more concerned with the internal coordination of the intelligence institutions, bringing about the emergence of sectoral egos from each parties which asses that they are better than others.

Therefore, conclusions from the results of research that have been formulated are as follows.

1. The legal basis (Laws and Regulations) is a significant foundation in determining coordination among national intelligence institutions. Thus, there is a need on a legal policy that has an existence and responsiveness. Therefore, legal basis is a policy and order that contains various policies of coordination between intelligence institutions, which has several functions, namely;

a. Strengthen and clarify coordination mechanisms among state intelligence institutions

b. Can identify the objectives of intelligence institutions

c. Can arrange strategies or tactics from various steps to achieve the desired objectives of intelligence institutions

d. Act as a source of the provision of various coordination inputs in the operational implementation of intelligence agencies from the tactics or strategies that have been prepared

There is a need for a process of transformation of interdependence coordination among state intelligence institutions in Indonesia, which consists of;

a. Pooled interdependence, which is a coordination aimed at achieving the tasks of intelligence institutions in accordance with the applicable Laws and Regulations.

b. Sequential interdependence, which is routine coordination and requires rules and procedures as well as scheduling and planning.

c. Mutual reciprocal interdependence, which is a coordination to achieve common goals on the basis of regulations and procedures, through scheduling and reciprocal adjustment.

Differences in attitudes in coordination should be a strong correlation in achieving state intelligence goals. This difference can occur, but keep in mind that; "Coordination is a synchronous and orderly effort to provide the right amount and time and direct the implementation to produce a uniform and harmonious action on the targets set in achieving intelligence objectives". Therefore, differences in attitudes need to be integrated and harmonized. For example, if customs intelligence gets information that there will be smuggling of goods from abroad, and the information is obtained from clear parties or people, then this information must be submitted to TNI, POLRI, and other intelligence institutions that have close links with smuggling activities. So that differences in attitudes and ways of working in the implementation of coordination need not be questioned in depth, but what needs to be considered is good coordination to achieve the security, comfort and integrity of the Republic of Indonesia.

Reform requires a more robust organizational design so that the coordinator between state intelligence institutions is clearly visible in BIN as its coordinator. Thus, a solution that can be implemented is organizational restructuring. The structure is planned and is a deliberate attempt to establish a pattern of relations between various components, so that it can reach the target effectively. As a form of formalization (formal affirmation) to achieve coordination between the patterns of interaction that occur or happen among organizational personnel that unite the coordination among state intelligence institutions, an organization that is good at integrating coordination among state intelligence institutions in Indonesia will have positive impact on the performance of state intelligence institutions in Indonesia.

2. SWOT analysis of coordination among state intelligence institutions is one of the fundamentals of increasing the effectiveness of coordination; 
a. Strengths. The resources owned by each state intelligence institution, especially those owned by the TNI and POLRI, can be used as basic capital in improving coordination between the existing state intelligence institutions. So that other countries' intelligence institutions can use strategies that are collaborated from TNI and POLRI to support intelligence interests in carrying out their tasks.

b. Weaknesses. All forms of weakness that exist from each intelligence institution are immediately anticipated so that it does not become a bigger gap, which is increasingly difficult to coordinate between state intelligence institutions. Intelligence institutions that have advantage should make use of it as much as possible and wisely to overcome the weaknesses of other intelligence institutions.

c. Opportunities. The organization of intelligence institutions that have been formed is a great opportunity to unite the coordination mechanism in various intensity of operational intelligence institutions. Establishing harmonious communication is a requirement to achieve harmonious coordination among state intelligence institutions.

d. Threats. Every threat that exists in each intelligence institution must be mapped and minimized as small as possible, then making threats as an in-depth study so that they can bring benefits in formulating plans and policies to develop better coordination.

The strategy applied in this case is Weaknesses - Threats (WT), namely by minimizing weaknesses and distance challenges in coordination between the state intelligence institutions. Then a strategy to improve effective coordination is developed.

3. The reform of state intelligence institutions that have been carried out needs to be supported by coordination reforms between state intelligence institutions that are still untouched. Coordination reforms between state intelligence institutions are carried out by doing the Organizational Re-Structuring of Intelligence Institutions according to the Craft Organization Type and also Coping Organization Type, namely organizations that have clear and measurable characteristics of process performance, but the output is unclear and not measurable, but the results clear and measurable.

4. Innovation in coordination among state intelligence institutions needs to be carried out in order to realize effective coordination, namely by;

a. Forming Intelligence Analysis Data Coordination Center (Puskotalis Intelijen) as a coordinator in a structurally consisting of representatives from each state intelligence institution and led by an expert or intelligence expert who has high intelligence competency. This intelligence center can guarantee coordination among state intelligence institutions permanently among state intelligence institutions; Determining principles and mechanisms for coordinating implementation that are robust in identifying country threats, hazards and risks, so they can work together specifically; Providing recommendations to the president and ministers through the relevant BIN Head about the priority of gathering intelligence needed by the state, clear assignment assignments and missions among different intelligence institutions, and not overlapping each other; Achieving the goals of an organized national security system from each intelligence institution in accordance with the rights and obligations carried out by intelligence institutions.

b. Establishing a Strategy based on SWOT and Re-Movement, namely uniting the strengths possessed by intelligence institutions into implementing sources of coordination; covering and weaknesses with collaborative operational capabilities; developing all opportunities that exist; and eliminating threats and even making them potential early detection and warning. Strategies can also be arranged using the mapping of Reinvention, Reengineering, and Restructuring of intelligence so that it can support the overcoming of inaccuracy of organizational structure design in overcoming crucial problems.

c. Building a model of coordination between effective state intelligence institutions compiled in a unified Coordination System (Polled) with the support of Network Type Command (NTC), namely the development of HTM, MTM and NTM models. The NTC model is a large coordination model with a broad network but still under one control or command, so that information processing can become increasingly faster and more accurate which in turn can increase high power in carrying out early detection and warning. In addition, it is also able to make a more significant contribution in developing the operational plans and strategies of state intelligence institutions in order to achieve the role, purpose and function of state intelligence effectively.

5. The complexity of coordination among state intelligence institutions in Indonesia can also be supported by establishing a National Security Council so that military and non-military intelligence institutions can meet to coordinate, this is considered capable of making a positive contribution in realizing the same understanding so that the coordination mechanism among state intelligence institutions is increasingly more effective.

\section{References}

Anggoro, K. 2008. Mekanisme Koordinasi Dalam Organisasi. Universitas Gajah Mada Press. Yogyakarta. 
Frederickson, George. H. 2010. Social Equity and Public Administration. Origins, Developments and Applications. M.E. Sharpe, Inc. Business Park Drive, Armonk, New York 10504.

Jeffray, T. R. 2016. The U.S. Intelligence Community. Seventh Edition. Published by Westview Press, 2465 Central Avenue, Boulder. CO. 80301

Karen, Lize Burger. 2008. A Comparative Analysis Of Intelligence Coordination After The 9/11 Attack And The Second Gulf War : Selected Case Studies. University of Pretoria.

Khamdani, Muh. 2014. Koordinasi Dalam Pencapaian Kerja Organisasi. Jurnal BPSDM Hukum dan HAM, published on February $24^{\text {th }}, 2014$.

Miles, M.B., Huberman, A.M., Saldana, J. 2014. Qualitative Data Analysis: A Methods Sourcebook (Third Edition). USA: Sage Publications. Translated by T.R. Rohidi. Jakarta: UI-Press.

Mintzberg, Henry. 1996. The Structuring of Organizations a Synthesis of the Research. Englewood Cliffs N.J.: Prentice-Hall, Inc.

Muluk, M.R.K 2006. Pengembangan Kelembagaan. Malang: Fakultas Ilmu Administrasi Universitas Brawijaya.

Scott, Richard W. 2008. Institutions and Organizations Foundations for Organizational Science: Foundations for Organizational Science. A Sage Publications Series. Sage Publications, Inc.

Sinuff, T., Cook, D., Giacomini, M., Heyland, D., Dodek, P. 2007. Facilitating clinician adherence to guidelines in the intensive care unit: A multicenter, qualitative study. Critical Care Medicine, 35(9):2083-9.

Terry, G.R. 1968. Principles of Management. IL: Richard D. Irwin Inc.

Verhoest, K and Geert Bouckaert, B. 2010. The Coordination Of Public Sector Organizations. Shifting Patterns of Public Management Basingstoke, Hampshire RG21 6XS, England

Wilson, James Q. 1989. Bureaucracy: What Government Agencies Do and Why They Do It. US: BasicBooks a Division of Harper Collins Publishers.

William, Samuel. S. 2017. British Security Coordination : The Secret History of British Intelligence in the Americas 1940 - 1945 ( 1999-06-01). The Washington, Post.

Yukl, Gary. 2010. Kepemimpinan Dalam Organisasi. Edisi kelima. Penerbit, PT Indeks. Jakarta.

Zauhar, Soesilo. 2001. Reformasi Administrasi. Konsep, Dimensi dan Strategi, Bumi Aksara, Jakarta. 